\title{
Perbandingan Kinerja Reksadana Konvensional dengan Syariah
}

\author{
Trie Utari Handayani ${ }^{1}$, Perdana Wahyu Santosa ${ }^{2}$, Any Setianingrum ${ }^{3}$ \\ ${ }^{1}$ Fakultas Ekonomi dan Bisnis, Universitas YARSI, Jakarta \\ 2,3 Program Magister Manajemen, Universitas YARSI, Jakarta
}

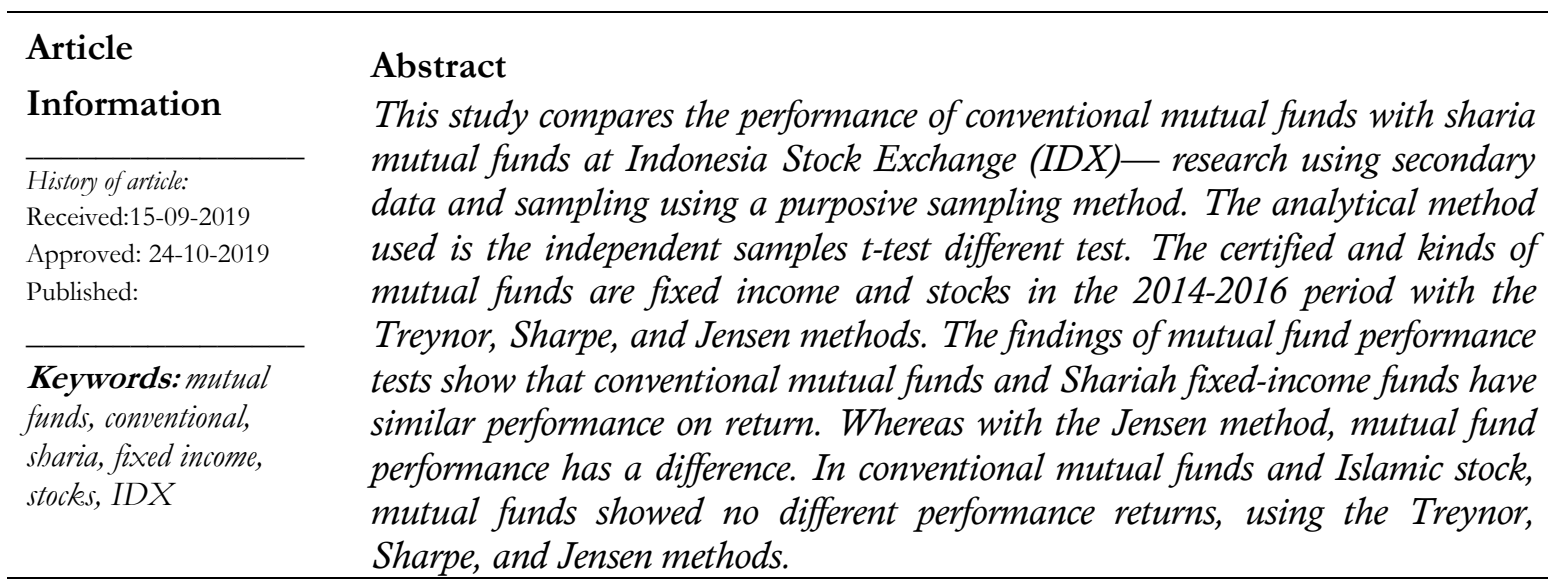

\begin{abstract}
Abstrak
Penelitian ini membandingkan kinerja reksadana konvensional dengan reksadana syariah di Bursa Efek Indonesia (BEI). Penelitian menggunakan data sekunder dan pengambilan sampel menggunakan metode purposive sampling. Metode analisis yang digunakan adalah uji beda independent samples $\mathrm{t}$ test. Reksadana yang diuji adalah pendapatan tetap dan saham dengan periode 2014-2016 dengan motode Treynor, Sharpe dan Jensen.Temuan pengujian kinerja reksadana menunjukkan bahwa reksadana konvensional dan reksadana syariah pendapatan tetap mempunyai kinerja yang tidak berbeda pada imbal hasilnya. Sedangkan dengan metode Jensen kinerja reksadana mempunyai perbedaan. Pada reksadana konvensional dan reksadana syariah saham menunjukkan kinerja return yang tidak berbeda, menggunakan metode Treynor, Sharpe dan Jensen.

JEL Classification: G24
\end{abstract}

Katakunci:

reksadana, konvensional, syariah, pendapatan tetap, saham, BEI.

\footnotetext{
${ }^{\square}$ correspondence to: Perdana Wahyu Santosa

E-mail: perdana.wahyu@yarsi.ac.id
}

ISSN 2527-7499 (print); 2528-3634 (online)

\section{PENDAHULUAN}

Pertimbangan utama investor adalah kinerja reksadana, risiko, biaya, harga atau NAB/unit, nilai dana yang dikelola reksadana, laporan investasi dan komunikasi dengan manajer investasi. Meningkatnya minat investor terhadap reksadana di Indonesia dalam beberapa tahun terakhir merupakan hal yang menggembirakan, namun faktor risiko dan kredibilitas manajer investasi dan pengalaman dalam mengelola dana harus dipertimbangkan dengan baik (Bodie et al. 2014; Santosa dan Puspitasari, 2019). Sejalan dengan beragamnya reksadana yang ditawarkan dan dikelola manajer investasi yang berbeda serta memiliki portofolio investasi yang berbeda pula, maka investor perlu melakukan seleksi terhadap reksadana yang dipilihnya. Umumnya seleksi terhadap reksadana saham dilakukan dengan melalui pengamatan terhadap kinerja reksadana saham tersebut. Kinerja reksadana berarti kemampuan 
reksadana menghasilkan return. Artinya investor memilih reksadana yang mampu memberikan return yang sesuai dengan risiko yang ada (Bodie et al, 2014; Jones, 2014; Tendelilin, 2012).

Dalam menghasilkan suatu kinerja investasi selalu ada faktor risiko yang terlibat. Begitu juga dalam reksadana, informasi mengenai risiko menjadi penting dalam membandingkan kinerja investasi reksadana. Pengukuran kinerja dengan mempertimbangkan faktor risiko memberikan informasi bagi investor tentang sejauh mana suatu hasil atau kinerja yang diberikan manajer investasi dikaitkan dengan risiko yang diambil untuk mencapai kinerja tersebut. Pengukuran kinerja reksadana juga dilihat dari besarnya NAB/unit dan return yang dihasilkan (Kasmiati dan Santosa, 2019; Jones, 2017; Bodie et al. 2014).

Reksadana konvensional mengalami peningkatan setiap tahunnya dari tahun 2010 berjumlah 564 dan pada tahun 2016 berjumlah 1289 tetapi pada awal januari 2016 jumlah reksadana konvensional mengalami penurunan dan kembali naik, jumlah tersebut berada diatas reksadana syariah. Tetapi reksadana syariah juga mengalami peningkatan yang signifikan dari tahun 2010 berjumlah 48 dan tahun 2016 berjumlah 136 dari hasil tersebut membuktikan bahwa walaupun reksadana syariah berjumlah lebih sedikit dari reksadana konvensional, keduanya tetap mengalami peningkatan.

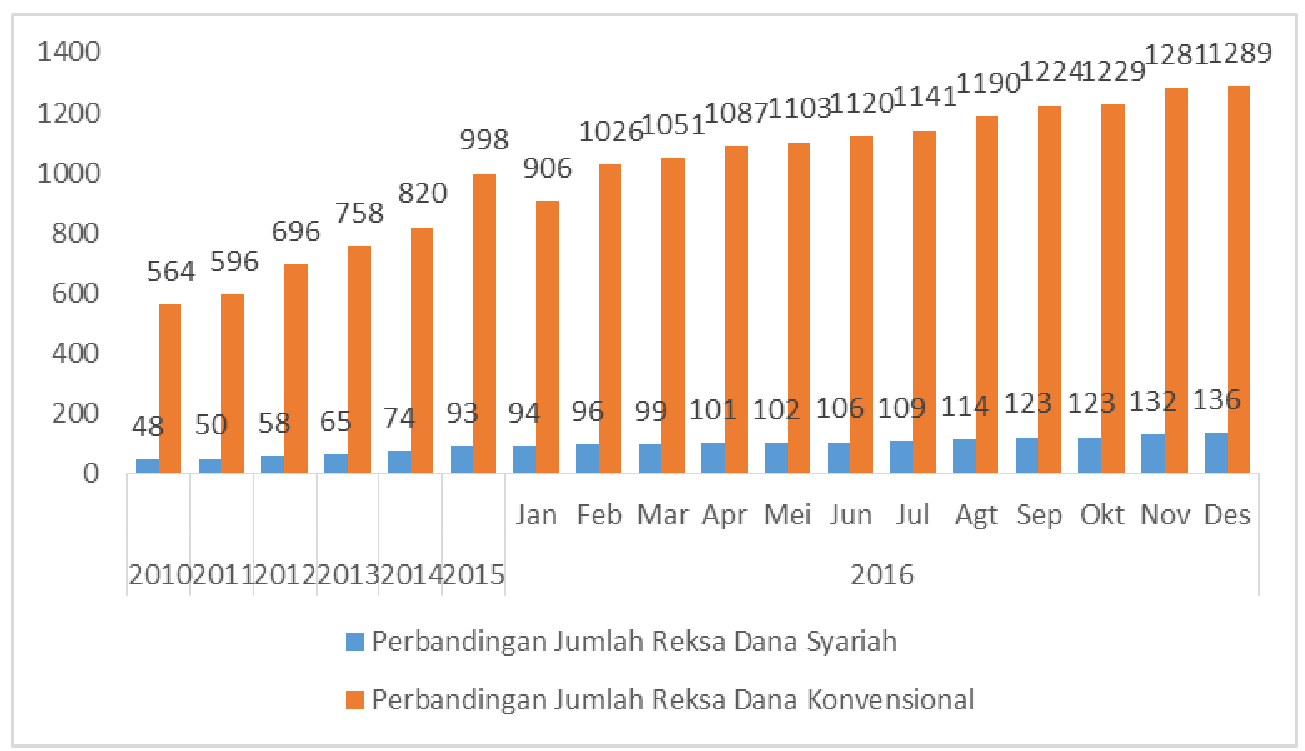

Gambar 1. Perbandingan Jumlah Reksadana Syariah Dan Konvensional

Sumber : www.ojk.go.id

Seorang investor yang rasional sebelum mengambil keputusan investasi, paling tidak harus mempertimbangkan 2 (dua) hal, yaitu pendapatan yang diharapkan (expected return) dan risiko (risk) yang terkandung dari alternatif investasi yang dilakukannya. Salah satu media investasi yang sering dipilih oleh investor adalah jenis reksadana (Winda, 2014; Pujiarti et al, 2011). Beberapa keuntungan berinvestasi dalam reksadana adalah investor dapat melakukan investasi dengan dana terbatas. Investor yang tidak memiliki banyak waktu dan pengetahuan untuk menghitung risiko atas investasi mereka tidak perlu khawatir, karena adanya manajer investasi yang mengelola investasi tersebut (Magdalena et al, 2012).

Tujuan artikel ini adalah membandingkan kinerja reksadana konvensional dan syariah menggunakan metode Sharpe, Treynor dan Jensen. Analisis perbandingan dilakukan pada reksadana 
pendapatan tetap dan reksadana saham dari kelompok konvensional dan syariah. Penelitian dilakukan pada periode 2012-2016.

\section{TINJAUAN PUSTAKA}

Samsul (2015) pasar modal mengalami kemajuan yang sangat pesat sejak deregulasi tahun 1998. Pasar modal merupakan suatu alternatif bagi para pemodal untuk berinvestasi. Perkembangan pasar modal mempunyai peranan yang penting bagi kemajuan ekonomi nasional di Indonesia. Dalam pasar modal terdapat dua unsur yang terkait, yaitu pihak yang bersedia membeli saham atau obligasi dan pihak yang menawarkan saham dan obligasi kepada masyarakat atau investor.

Menurut Ekananda (2019), jenis-jenis reksadana yang tersedia di Indonesia ada empat berdasarkan kategori insturmen, yaitu reksadana pasar uang, reksadana pendapatan tetap, reksadana saham dan reksadana campuran. Setiap jenis reksadana melakukan investasi yang berbeda-beda. Reksadana pendapatan tetap yang 80 persen portofolio investasinya pada efek yang berbentuk surat utang seperti obligasi. Reksadana pasar uang yang portofolionya investasinya pada jenis instrumen pasar uang seperti SBI. Reksadana saham yang portofolionya investasinya terdiri dari saham. Reksadana campuran yang instrumen investasinya bisa berbentuk saham dan obligasi atau dikombinasikan dengan instrumen lainnya. Setiap jenis reksadana juga memiliki kinerja yang berbeda-beda yang dilihat dari nilai aktiva bersih setiap jenis reksadana.

Dalam pasar modal para investor dapat menginvestasikan dananya pada sekuritas yang dikehendaki dan yang memiliki tingkat risiko yang dapat mereka terima. Dalam investasi di pasar modal dapat memiliki return yang tinggi tetapi dapat juga memiliki tingkat risko yang tinggi. Dengan demikian investor harus memiliki strategi dalam berinvenstasi pada sekuritas yang tepat dengan memiliki tingkat risiko yang dapat diterima. Sebelum berinvestasi direksadana kita perlu mengetahui jenis reksadana yang sesuai dengan tujuan dan kebutuhan investasi kita (Bodie et al. 2014; Jones, 2017).

\section{Kinerja Reksadana}

Kinerja reksadana merupakan suatu analisis yang dilakukan untuk melakukan evaluasi dan mengetahui perkembangan reksadana yang selama ini dikelola diperiode tertentu. Kinerja reksadana penting bagi investor untuk membuat suatu keputusan melakukan investasi dengan melihat kinerja reksadana masa lalu. Kinerja reksadana yang baik dimasa lalu bukanlah suatu jaminan untuk mendapatkan suatu kinerja yang baik juga diwaktu yang akan datang, tetapi kinerja yang baik dimasa lalu merupakan suatu peluang untuk mendapatkan kinerja yang baik juga untuk waktu yang akan datang. NAB per unit merupakan suatu data yang dibutuhkan untuk menilai kinerja reksadana (Ekananda, 2019; Jones, 2017; Santosa dan Laksana, 2010).

Ada banyak faktor yang mempengaruhi kinerja reksadana, yaitu pertama, faktor lingkungan reksadana tersebut terutama kebijakan pemerintah dalam bidang moneter, dengan maksud apabila pemerintah menurunkan tingkat sukubunga SBI akan sangat menguntungkan reksadana karena tingkat bunga SBI yang tidak turun secara langsung dapat menurunkan tingkat bunga obligasi yang dipegang reksadana sehingga kupon bunga yang dipegang oleh reksadana masih tetap menggunakan kupon lama (Ekananda, 2019; Bodie et al. 2014). Kedua, faktor pengelolaan reksadana, kesalahan dalam mengelola dan mengalokasikan saham yang berpengaruh besar terhadap kinerja reksadana yang bersangkutan (Samsul, 2015). Peraturan Bapepam nomor IV.B.1 yaitu memberikan batasan atas pengelolaan investasi bahwa sebuah reksadana tidak dapat mengalokasikan asetnya melebihi 10 persen dari total asetnya kepada suatu pihak atau melebih 5 persen dari emisi emiten yang bersangkutan. Ketiga, market timing, pembelian instrument investasi merupakan salah satu faktor penting untuk peningkatan kinerja portofolio atau reksadana. Market timing ini cocok untuk manajer investasi yang mengelola reksadana. 


\section{Penelitian Terdahulu}

Beberapa penelitian terdahulu yang relevan dan terkait langsung memberikan kontribusi pada studi ini dapat dirangkum pada Tabel 1 di bawah ini.

\section{Tabel 1. Penelitian Terdahulu}

\begin{tabular}{|c|c|c|}
\hline Peneliti dan Judul & Model & Hasil dan Konklusi \\
\hline $\begin{array}{l}\text { Reny Nur Fikasari } 2012 \\
\text { Analisis Komparatif } \\
\text { Kinerja Reksadana } \\
\text { Syariah Indonesia Dan } \\
\text { Malaysia Dengan } \\
\text { Metode Sharpe, Treynor, } \\
\text { dan Jensen. }\end{array}$ & $\begin{array}{l}\text { Metode } \\
\text { Sharpe, } \\
\text { Treynor, dan } \\
\text { Jensen }\end{array}$ & $\begin{array}{l}\text { - Kinerja reksadana syariah Indonesia dan Malaysia } \\
\text { perbandingan kinerja reksadana Indonesia dan } \\
\text { Malaysia } 27 \text { reksadana syariah Indonesia dan } 77 \\
\text { reksadana syariah malaysia indeks Sharpe, indeks } \\
\text { Treynor, dan indeks Jensen berdasarkan hasil } \\
\text { perhitungan model Sharpe, Treynor, dan Jensen } \\
\text { - Sebagian besar kinerja reksadana syariah Indonesia } \\
\text { dan Malaysia tahun } 2008 \text { mengalami penurunan } \\
\text { yang disebabkan oleh imbas krisis finansial global. } \\
\text { - Pada tahun } 2009 \text { rata-rata kinerja reksada syariah } \\
\text { kedua negara sudah mulai membaik,tetapi jika } \\
\text { dibandingkan tingkat pertumbuhannya Malaysia } \\
\text { lebih tinggi dibanding Indonesia dan Malaysia } \\
\text { mengalami perkembangan yang cukup pesat } \\
\text { - Secara keseluruhan hasil menyatakan bahwa ada } \\
\text { perbedaan kinerja syariah Indonesia dan Malaysia. }\end{array}$ \\
\hline $\begin{array}{l}\text { Vince Ratnawati dan } \\
\text { Ningrum Khairani } \\
\text { (2012) Perbandingan } \\
\text { Kinerja Reksadana } \\
\text { Syariah Dan Reksadana } \\
\text { Konvensional }\end{array}$ & $\begin{array}{l}\text { Metode } \\
\text { Sharpe, Treynor } \\
\text { dan Jensen }\end{array}$ & $\begin{array}{l}\text { - Hasil pengujian hipotesis menunjukan bahwa rata- } \\
\text { rata kinerja reksadana pendapatan tetap } \\
\text { konvensional dan syariah menunjukan hasil yang } \\
\text { tidak berbeda } \\
\text { - Sedangkan hasil pengujian hipotesis menunjukan } \\
\text { bahwa rata-rata kinerja reksadana campuran } \\
\text { konvensional dan syariah menunjukan perbedaan } \\
\text { yang signifikan }\end{array}$ \\
\hline $\begin{array}{l}\text { Ricke Yuliaty (2013) } \\
\text { Analisis Komparatitif } \\
\text { Kinerja Reksadana } \\
\text { Saham Konvensional } \\
\text { Dengan Reksadana } \\
\text { Saham Syariah Dengan } \\
\text { Menggunakan Model } \\
\text { Treynor, Sharpe, Dan } \\
\text { Jensen Periode } 2010\end{array}$ & $\begin{array}{l}\text { Model } \\
\text { Treynor, } \\
\text { Sharpe, Jensen, } \\
\text { Treynor \& } \\
\text { black }\end{array}$ & $\begin{array}{l}\text { - Model Treynor dan Jensen menyimpulkan hasil serupa } \\
\text { dalam pemeringkatan reksadana, yang } \\
\text { menggunakan acuan pasar untuk menghitung risiko } \\
\text { reksadana. Serta pada model Sharpe maupun Treynor } \\
\text { \& Black didapatkan hasil yang acak, dikarenakan } \\
\text { karena kedua model tersebut menggunakan risiko } \\
\text { total. } \\
\text { - Berinvestasi pada reksadana saham dipasar modal } \\
\text { tergolong menguntungkan sebab dari pengamatan } \\
\text { terhadap } 23 \text { reksadana saham diperoleh hasil bahwa } \\
\text { reksadana yang tidak layak untuk dipilih maksimal } \\
10 \text { reksadana atau kurang dari } 50 \% \text { dari reksadana } \\
\text { yang diamati. }\end{array}$ \\
\hline $\begin{array}{l}\text { Mulya Ryady Esha, } \\
\text { Mohamad Heykal dan } \\
\text { Titik Indrawati (2014) } \\
\text { Analisis Perbandingan } \\
\text { Reksadana Saham }\end{array}$ & $\begin{array}{l}\text { Metode } \\
\text { annual return, } \\
\text { Sharpe, } \\
\text { Treynor, Jensen }\end{array}$ & $\begin{array}{l}\text { - Hasil independent samples test menunjukkan } \\
\text { bahwa return tingkat signifikansinya } 0,790>0,05 \text {, } \\
\text { indeks Sharpe tingkat signifikansinya } 0,656>0,05 \\
\text { dan indeks Treynor tingkat signifikansinya } 0,884> \\
\text { 0,05, sehingga Ha ditolak atau Ho diterima artinya }\end{array}$ \\
\hline
\end{tabular}




\begin{tabular}{|c|c|c|}
\hline $\begin{array}{l}\text { syraiah-Reksadana } \\
\text { Konvensional }\end{array}$ & dan snail trail & $\begin{array}{l}\text { tidak ada perbedaan signifikan antara kinerja } \\
\text { reksadana saham konvensional dan kinerja } \\
\text { reksadana saham syariah. } \\
\text { - Terdapat perbedaan signifikan antara kinerja } \\
\text { reksadana saham konvensional dan kinerja } \\
\text { reksadana saham syariah. } \\
\text { - Kinerja reksadana saham syariah lebih baik dari } \\
\text { reksadana saham konvensional tetapi dalam jumlah } \\
\text { NAB reksadana konvensional lebih besar dari NAB } \\
\text { reksadana syariah. }\end{array}$ \\
\hline $\begin{array}{l}\text { Rininta Liyanasari } \\
\text { (2014) Analisis } \\
\text { Perbandingan Kinerja } \\
\text { Portofolio Optimal } \\
\text { Pada Saham Syariah } \\
\text { Indonesia Dan Saham } \\
\text { Syariah Malaysia } \\
\text { Periode 2009-2012 }\end{array}$ & $\begin{array}{l}\text { Model Sharpe, } \\
\text { Treynor, dan } \\
\text { Jensen }\end{array}$ & $\begin{array}{l}\text { - Menyimpulkan bahwa hipotesis alternatif diterima } \\
\text { yang berarti terdapat perbedaan signifikan antara } \\
\text { kinerja portofolio optimal saham syariah Indonesia } \\
\text { dan saham syariah Malaysia } \\
\text { - Diukur berdasarkan model Sharpe Treynor dan Jensen. } \\
\text { Dan dari hasil uji statistic didapatkan hasil bahwa } \\
\text { kinerja saham syariah Indonesia lebih rendah dari } \\
\text { kinerja saham syariah Malaysia. }\end{array}$ \\
\hline $\begin{array}{l}\text { Jepryansyah Putra Dan } \\
\text { Syarief Fauzie (2015) } \\
\text { Analisis Perbandingan } \\
\text { Kinerja Reksadana } \\
\text { Konvensional Dengan } \\
\text { Reksadana Syariah Di } \\
\text { Indonesia }\end{array}$ & $\begin{array}{l}\text { Metode } \\
\text { Sharpe ratio, } \\
\text { Treynor ratio } \\
\text { dan } \\
\text { ratio }\end{array}$ & $\begin{array}{l}\text { - Kinerja reksadana saham dengan Sharpe ratio dan } \\
\text { Treynor ratio pada tingkat kesalahan }(\alpha) 5 \% \\
\text { disimpulkan tidak terdapat perbedaan signifikan } \\
\text { antara kedua kelompok reksadana. Sedangkan } \\
\text { dengan Jensen ratio disimpulkan ada perbedaan } \\
\text { signifikan pada kinerja kedua kelompok reksadana. } \\
\text { - Kinerja reksadana campuran dengan Sharpe ratio, } \\
\text { dan Treynor ratio pada tingkat kesalahan }(\alpha) 5 \% \\
\text { disimpulkan tidak terdapat perbedaan signifikan } \\
\text { antara reksadana konvensional dan reksadana } \\
\text { syariah. Namun rata-rata kinerja reksadana syariah } \\
\text { lebih baik dibandingkan reksadana pendapatan } \\
\text { tetap konvensional. }\end{array}$ \\
\hline $\begin{array}{l}\text { Kartini dan Rico } \\
\text { Febriyanto (2015) } \\
\text { Analisis Perbandingan } \\
\text { Kinerja Reksadana } \\
\text { Konvensional Dengan } \\
\text { Reksadana Syariah Di } \\
\text { Indonesia }\end{array}$ & $\begin{array}{l}\text { Metode } \\
\text { Sharpe } \\
\text { Treynor }\end{array}$ & $\begin{array}{l}\text { - Hasil independent sampel test menunjukkan bahwa } \\
\text { indeks Sharpe memiliki t hitung } 0,225<\mathrm{t} \text { tabel } \\
1,663 \text { atau tingkat signifikansinya } 0,822>0,05 \text {, } \\
\text { sehingga ha ditolak atau ho diterima artinya tidak } \\
\text { ada perbedaan signifikan antara kinerja reksadana } \\
\text { saham konvensional dan kinerja reksadana saham } \\
\text { syariah berdasarkan indeks Sharpe. } \\
\text { - Sedangkan untuk indeks Treynor t hitung 0,872<t } \\
\text { tabel 1,734 atau tingkat signifikansinya 0,395 > } \\
\text { 0,05, sehingga ha ditolak atau ho diterima artinya } \\
\text { tidak ada perbedaan signifikan antara kinerja } \\
\text { reksadana saham konvensional dan kinerja } \\
\text { reksadana saham syariah berdasarkan indeks } \\
\text { Treynor. }\end{array}$ \\
\hline
\end{tabular}




\section{Hipotesis Penelitan}

Penelitian ini dibuat untuk mengetahui perbandingan antara reksadana konvensional dengan reksadana syariah yang terdiri dari reksadana pendapatan tetap dan reksadana saham. Berikut adalah hipotesis penelitian ini:

H1: Terdapat perbedaan kinerja reksadana pendapatan tetap konvensional dengan reksadana pendapatan tetap syariah

H2: Terdapat perbedaan kinerja reksadana saham konvensional dengan reksadana saham syariah

\section{DATA DAN METODOLOGI}

\section{Jenis Data dan Teknik Pengambilan Data}

Penelitian ini menggunakan data sekunder yang sebelumnya telah dikumpulkan oleh berbagai pihak. Selanjutnya data dikumpulkan dengan teknik dokumentasi. Data diambil melalui berbagai situs internet penyedia data yang berkaitan dengan analisis kinerja reksadana, yaitu:

a. Website www.ojk.go.id untuk mendapatkan data reksadana dan NAB bulanan

b. Website www.bi.go.id untuk mendapatkan informasi mengenai data BI rate dan tanggal perubahan BI rate pada tahun 2015-2016.

c. Website www.finance.yahoo.com untuk mendapatkan data bulanan IHSG dan JII pada tahun 2014-2016

\section{Definisi Operasional dan Pengukuran Variabel}

Variabel yang digunakan dalam penelitian ini adalah sebagai berikut:

a. Return manajer investasi adalah tingkat pengembalian yang diperoleh investor dari sejumlah dana yang diinvestasikan disebuah reksadana saham pada suatu periode tertentu. Nilai return manajer investasi ini diperoleh dari NAB per unit penyertaan untuk masing-masing manajer investasi. Rumus yang digunakan adalah:

$$
R d=\frac{N A B t-N A B t-1}{N A B t-1}
$$

Dimana:

$R d=$ return Reksadana saham

$N A B t=\mathrm{NAB}$ pada periode pengukuran

$N A B t-1=\mathrm{NAB}$ pada periode sebelum pengukuran

b. Return Pasar adalah tingkat keuntungan yang diperoleh dari kinerja pasar. Terdapat dua variabel pembanding (benchmark) yang digunakan dalam penelitian ini yaitu, return Indeks Harga Saham Gabungan. Adapun rumus yang digunakan adalah:

Dimana:

$$
R M 1=\frac{\text { IHSGt-IHSGt-1 }}{\text { IHSGt-1 }}
$$

$R \mathrm{M} 1=$ Return IHSG

$I H S G t=$ IHSG pada periode pengukuran

IHSG $t-1=$ IHSG pada periode sebelum pengukuran

c. Return Pasar syariah adalah tingkat keuntungan yang diperoleh dari kinerja pasar. Terdapat dua variabel pembanding yang digunakan dalam penelitian ini yaitu, return Jakarta Islamic Index. Adapun rumus yang digunakan adalah:

$$
R M 2=\frac{M I t-J H t-1}{J I I t-1}
$$

Dimana: 


$$
\begin{array}{ll}
R \mathrm{M} 2 & =\text { Return } \mathrm{JII} \\
\mathrm{JII} t & =\mathrm{JII} \text { pada periode pengukuran } \\
\mathrm{JII} t-1 & =\mathrm{JII} \text { pada periode sebelum pengukuran }
\end{array}
$$

d. Keuntungan Bebas Risiko Keuntungan bebas risiko adalah keuntungan yang diperoleh dari instrumen investasi yang memiliki risiko sangat kecil. Investasi bebas risiko diukur menggunakan BI rate. BI rate adalah suku bunga kebijakan moneter yang ditetapkan oleh Bank Indonesia dan diumumkan kepada publik.

\section{Populasi dan Sampel}

Populasi dalam penelitian ini adalah seluruh manajer investasi yang terdaftar di OJK. Berdasarkan data yang diperoleh terdapat 85 manajer investasi yang masih aktif dan tercatat pada OJK sampai Januari 2017. Penelitian ini menggunakan metode purposive sampling dalam pengambilan sampel, yaitu pengambilan sampel yang menyesuaikan dengan kriteria tertentu. Kriteria sampel yang digunakan dalam penelitian ini yaitu:

a. Terdaftar diOJK

b. Mempunyai produk reksadana saham dan pendapatan tetap di dalam konvensional maupun syariah

c. Menggunakan mata uang rupiah

d. Mempunyai data yang lengkap di web OJK dari tahun 2014-2016

Dari kretaria diatas dalam pengambilan sampel maka diperoleh sebanyak 4 Manajer Investasi yang dijadikan sampel penelitian.

Tabel 2. Daftar Manajer Investasi

\begin{tabular}{ll}
\hline No. & Manajer Investasi \\
\hline 1 & Mandiri Manajemen Investasi, PT \\
2 & MNC Asset Management, PT \\
3 & PNM Investment Management, PT \\
4 & Samuel Aset Manajemen, PT \\
\hline \multicolumn{2}{l}{ Sumber: BEI (2017) }
\end{tabular}

\section{Teknik Analisis Data}

Data yang diperoleh dari berbagai sumber dianalisa secara deskriptif kuantitatif. Data yang dikumpulkan diolah dengan rumus-rumus sesuai dengan definisi operasional variabel yang relevan menggunakan bantuan program Microsoft Excel untuk mempermudah pengolahan data. Langkahlangkah yang dilakukan adalah:

a. Melakukan pengumpulan data NAB untuk menghitung return reksadana, besarnya IHSG dan JII untuk return pasar dan rata-rata BI rate untuk risk free rate.

b. Menguji kinerja masing-masing manajer investasi menggunakan metode Sharpe. Metode Sharpe bertujuan untuk mengetahui besarnya penambahan hasil investasi yang diperoleh untuk tiap unit risiko yang diambil. Pengukuran kinerja manajer investasi menggunakan metode Sharpe didasarkan atas premi risiko dibagi dengan standar deviasi. Premi risiko yaitu selisih antara rata-rata kinerja yang dihasilkan Reksadana dengan rata-rata kinerja investasi bebas risiko, sedangkan standar deviasi menunjukkan penyimpangan yang terjadidari rata-rata kinerja yang dihasilkan. Rumus yang digunakan untuk menghitung kinerja manajer investasi menggunakan metode Sharpe adalah sebagai berikut:

$$
S_{p}=\frac{R g-R f}{G P}
$$


keterangan:

$S p=$ hasil kinerja menggunakan metode Sharpe

$R p=$ rata-rata return portofolio selama periode pengamatan

$R F=$ rata-rata tingkat return bebas risiko selama periode pengamatan

$\sigma p=$ standar deviasi return portofolio selama periode pengamatan

c. Menguji kinerja masing-masing manajer investasi menggunakan metode Treynor. Pengukuran kinerja Reksadana saham menggunakan metode Treynor dihitung dengan memperhatikan fluktuasi pasar. Dalam perhitungannya digunakan pembagi Beta $(\beta)$ yang merupakan risiko fluktuasi terhadap risiko pasar (Wahdah, 2012). Rumus yang digunakan untuk menghitung kinerja manajer investasi menggunakan metode Treynor adalah sebagai berikut:

$$
T p=\frac{k p-R f}{\beta p}
$$

keterangan:

$T p=$ hasil kinerja menggunakan metode Treynor

$R p=$ rata-rata return portofolio selama periode pengamatan

$R F=$ rata-rata tingkat return bebas risiko selama periode pengamatan

$\beta p=$ beta portofolio

d. Menguji kinerja masing-masing manajer investasi menggunakan metode Jensen. Pengukuran metode ini untuk mengukur rata-rata actual return terhadap theoritical return dari portofolio dengan menggunakan CAPM, yaitu sejauh mana reksadana dapat memberikan keuntungan diatas harga pasar. Adapun formula yang digunakan untuk menghitung kinerja Reksadana saham menggunakan metode Jensen adalah sebagai berikut:

$$
I p=R p-[R f+\beta p(R M-R f)]
$$

di mana:

j $p=$ hasil kinerja menggunakan metode Jensen

$R p=$ rata-rata return portofolio selama periode pengamatan

$R_{\mathrm{f}}=$ rata-rata tingkat return bebas risiko selama periode pengamatan

$R M=$ rata-rata return market (IHSG)

$\beta p=$ beta portofolio

\section{Teknik Pengolahan Data}

a. Uji Asumsi Klasik

Penggunaan model analisis terikat dengan sejumlah asumsi dan harus memenuhi asumsiasumsi klasik yang mendasari model tersebut. Pengujian asumsi yang harus dipenuhi agar Persamaan regresi dapat digunakan dengan baik (uji persyaratan analisis) sebagai berikut:

\section{Uji Normalitas}

Uji normalitas bertujuan untuk menguji apakah dalam model regresi variabel terikat dan variabel bebas keduanya apakah mempunyai distribusi normal atau tidak. Model regresi yang baik harus mempunyai distribusi normal atau mendekati normal (Santosa dan Hidayat, 2014). Uji normalitas pada penelitian ini menggunakan uji statistik non parametrik Kolmogorov Smirnov (K-S). Uji K-S dilakukan dengan membuat hipotesis:

Jika nilai Asymp. Sig. $(2-$ tailed $) \geq 0,05$ data berdistribusi normal 
Jika nilai Asymp. Sig. $(2-$ tailed $) \leq 0,05$ data tidak berdistribusi normal.

\section{Uji homogenitas}

Uji homogenitas adalah pengujian mengenai sama tidaknya variansi-variansi dua buah distribusi atau lebih. Uji homogenitas yang akan dibahas dalam tulisan ini adalah Uji Homogenitas Variansi. Uji homogenitas dilakukan untuk mengetahui apakah data dalam variabel X dan Y bersifat homogen atau tidak.

a) Jika F hitung > Tabel F: F Tabel dalam Excel berarti homogen

b) Jika F hitung < Tabel F: F Tabel dalam Excel berarti tidak homogeny

\section{b. Uji beda Independent Sample t-test}

Uji perbedaan untuk jenis penelitian yang menghasilkan data berskala interval, pada umumnya dimaksudkan untuk menguji perbedaan rata-rata hitung diantara kelompok-kelompok tertentu yang memiliki persyaratan tertentu yang diteliti. Teknik statistik yang dipergunakan pada umumnya adalah teknik t-test (Santosa dan Hidayat, 2014). Uji kesamaan dua rata-rata dilakukan untuk mengetahui apakah kedua sampel memiliki rata-rata relatif sama. Pengujian dilakukan dengan Uji t Beda Dua Sampel Tidak Berhubungan (Independent Sample t-test). Adapun dasar pengambilan keputusan dalam uji kesamaan dua rata-rata, sebagai berikut:

Jika nilai signifikansi (sig.) atau probabilitas $\geq 0.05$, maka Ho diterima.

Jika nilai signifikansi (sig.) atau probabilitas $<0.05$, maka Ho ditolak.

Atau keputusan dalam uji kesamaan dua rata-rata dengan Independent Sample t-test dapat dibandingkan dengan $\mathrm{t}$ tabel, yaitu:

Jika $-\mathrm{t}$ tabel $\leq \mathrm{t}$ hitung $\leq \mathrm{t}$ tabel, maka Ho diterima.

Jika $-\mathrm{t}$ tabel $>-\mathrm{t}$ hitung atau $\mathrm{t}$ hitung $>\mathrm{t}$ tabel, maka Ho ditolak

\section{ANALISIS DAN HASIL}

Berdasarkan dari pada data-data yang sudah diperoleh dan dihitung kemudian diuji dengan statistik untuk meguji normalitas data, Homogenitas data dan untuk uji independen t-test untuk membuktikan hipotesis yang ada diterima atau ditolak dengan menggunakan aplikasi SPSS versi 19.0. Berikut ini adalah hasil dari uji statistik:

Tabel 3. Hasil Uji Normalitas

One-Sample Kolmogorov-Smirnov Test

\begin{tabular}{|ll|r|r|r|r|}
\hline & & \multicolumn{1}{c|}{ Return } & \multicolumn{1}{c|}{ Treynor } & \multicolumn{1}{c|}{ Sharpe } & \multicolumn{1}{c|}{ Jensen } \\
\hline $\mathrm{N}$ & & 87 & 87 & 87 & 87 \\
Normal & Mean & 0.045006 & -0.034966 & -0.147851 & -0.016448 \\
Parameters $^{\text {a }}$ & Std. Deviation & 0.1516509 & 0.2286537 & 0.8997099 & 0.0612843 \\
& Absolute & 0.125 & 0.11 & 0.124 & 0.078 \\
Most Extreme & Positive & 0.082 & 0.11 & 0.063 & 0.077 \\
Differences & Negative & -0.125 & -0.09 & -0.124 & -0.078 \\
& 1.164 & 1.029 & 1.155 & 0.729 \\
Kolmogorov-SmirnovZ & 0.133 & 0.241 & 0.139 & 0.663 \\
Asymp. Sig. (2-tailed) & & & & \\
\hline
\end{tabular}

a. Test distribution is Normal.

Sumber: data diolah (2017) 
Dalam Tabel 3 hasil dari uji normalitas dengan menggunakan uji Kolmogorov-Smirnov $Z$ yang dilakukan menunjukan bahwa probabilitas (sig.) sebesar 0,133 pada return, 0,241 pada metode Treynor, 0,139 pade metode Sharpe, 0.663 pada metode Jensen. Hasil uji ini menunjukan bahwa return, Treynor, Sharpe dan Jensen mempunyai distribusi yang normal karena hasil uji normalitas sig $>0,05$ yaitu sig return 0,133>0,05 sig Treynor 0,241>0,05, sig Sharpe 0,139>0,05 dan sig Sharpe 0,663>0,05.

Tabel 4. Uji Homogenitas

ANOVA

\begin{tabular}{|c|c|c|c|c|c|c|}
\hline & & $\begin{array}{l}\text { Sum of } \\
\text { Squares }\end{array}$ & df & $\begin{array}{c}\text { Mean } \\
\text { Square }\end{array}$ & $F$ & Sig. \\
\hline \multirow{3}{*}{ Return } & $\begin{array}{l}\text { Between } \\
\text { Groups }\end{array}$ & 0.013 & 3 & \multirow{3}{*}{$\begin{array}{l}0.004 \\
0.024\end{array}$} & \multirow[t]{3}{*}{0.188} & \multirow[t]{3}{*}{0.904} \\
\hline & Within Groups & 1.964 & 83 & & & \\
\hline & Total & 1.978 & 86 & & & \\
\hline \multirow{3}{*}{ Treynor } & $\begin{array}{l}\text { Between } \\
\text { Groups }\end{array}$ & 0.088 & 3 & \multirow{3}{*}{$\begin{array}{l}0.029 \\
0.053\end{array}$} & \multirow[t]{3}{*}{0.55} & \multirow[t]{3}{*}{0.65} \\
\hline & Within Groups & 4.409 & 83 & & & \\
\hline & Total & 4.496 & 86 & & & \\
\hline \multirow{3}{*}{ Sharpe } & $\begin{array}{l}\text { Between } \\
\text { Groups }\end{array}$ & 0.445 & 3 & \multirow{3}{*}{$\begin{array}{l}0.148 \\
0.833\end{array}$} & \multirow[t]{3}{*}{0.178} & \multirow[t]{3}{*}{0.911} \\
\hline & Within Groups & 69.17 & 83 & & & \\
\hline & Total & 69.615 & 86 & & & \\
\hline \multirow{3}{*}{ Jensen } & $\begin{array}{l}\text { Between } \\
\text { Groups }\end{array}$ & 0.028 & 3 & \multirow{3}{*}{$\begin{array}{l}0.009 \\
0.004\end{array}$} & \multirow[t]{3}{*}{2.604} & \multirow[t]{3}{*}{0.057} \\
\hline & Within Groups & 0.295 & 83 & & & \\
\hline & Total & 0.323 & 86 & & & \\
\hline
\end{tabular}

Sumber: data diolah (2017)

Tabel 4. menunjukkan hasil uji homogenitas dengan menggunakan uji anova yang dilakukan menunjukan bahwa pada $\mathrm{F}$ hitung sebesar 0,188 pada return, 0,55 pada metode Treynor, 0,178 pada metode Sharpe, dan 2,604 pada metode Jensen. Hasil ini menunjukan bahwa hasil data reksadana konvensional dan reksadana syariah HOmogen karena F hitung return 0,188>0,0513 F tabel, F hitung Treynor 0,55> 0,0513 F tabel, F hitung pada metode Sharpe 0,178> 0,0513 F tabel, dan F hitung pada metode Jensen 2,604>0,0513 F tabel.

Probabilitas (sig.) pada return sebesar 0,904, metode Treynor sebesar 0,65, pada metode Sharpe 0,911, dan pada metode Jensen 0,057. Hasil uji ini menunjukan bahwa Treynor, Sharpe dan Jensen mempunyai variasi data reksadana konvensional dan syariah yang homogen karena sig return $0,904>$ 0,05, sig Treynor 0,241>0,05, sig Sharpe 0,911>0,05 dan sig Jensen 0,057>0,05.

Tabel 5. menunjukkan hasil uji independen $t$ test digunakan untuk menguji apakah kedua kelompok reksadana konvensional dan syariah pendapatan tetap memiliki rata-rata yang sama. Hasil dari independent $\mathrm{t}$ test yang dilakukan pada return didapatkan hasil T Tabel $-2.032 \leq \mathrm{T}$ hitung $-1,299 \leq$ T Tabel 2.032 dan sig (2-tailed) $0,203 \geq 0,05$, hal ini menunjukan bahwa ha ditolak atau Ho diterima artinya tidak ada perbedaan signifikan antara reksadana konvensional pendapatan tetap dan reksadana syariah pendapatan tetap yang diuji dengan return. 
Hasil dari independent $\mathrm{t}$ test yang dilakukan melalui index Treynor didapatkan hasil $\mathrm{T}$ hitung 0,636 $\leq$ T Tabel 2.032 dan sig (2-tailed) 0,529 $\geq 0,05$, hal ini menunjukan bahwa ha ditolak atau Ho diterima artinya tidak ada perbedaan signifikan antara reksadana konvensional pendapatan tetap dan reksadana syariah pendapatan tetap yang diuji dengan indeks Treynor.

Melalui index Sharpe didapatkan hasil T Tabel $-2.032 \leq \mathrm{T}$ hitung $-1,228 \leq \mathrm{T}$ Tabel 2.032 dan sig (2-tailed) 0,228 $\geq 0,05$, hal ini menunjukan bahwa ha ditolak atau Ho diterima artinya tidak ada perbedaan signifikan antara reksadana konvensional pendapatan tetap dan reksadana syariah pendapatan tetap yang diuji dengan indeks Sharpe.

Tabel 5. Uji Independent T-Test Konvensional dan Syariah Pendapatan Tetap

\begin{tabular}{|c|c|c|c|c|c|c|c|c|c|c|}
\hline & & & & & & & & & & \\
\hline & & $\begin{array}{l}\text { Levene } \\
\text { for Equ }\end{array}$ & & & & t-test & for Equality & of Means & & \\
\hline & & $\mathrm{F}$ & Sig. & $\mathrm{t}$ & df & $\begin{array}{l}\text { Sig. (2- } \\
\text { tailed) }\end{array}$ & $\begin{array}{c}\text { Mean } \\
\text { Difference }\end{array}$ & $\begin{array}{l}\text { Std. Error } \\
\text { Difference }\end{array}$ & $\begin{array}{r}95 \% \text { Co } \\
\text { Interva } \\
\text { Differ }\end{array}$ & $\begin{array}{l}\text { fidence } \\
\text { of the } \\
\text { ence }\end{array}$ \\
\hline & & & & & & & & & Lower & Upper \\
\hline Return & $\begin{array}{l}\text { Equal variances } \\
\text { assumed } \\
\text { Equal variances } \\
\text { not assumed }\end{array}$ & 6.443 & 0.016 & $\begin{array}{l}-1.299 \\
-1.675\end{array}$ & $\begin{array}{r}34 \\
32.903\end{array}$ & $\begin{array}{l}0.203 \\
0.103\end{array}$ & $\begin{array}{l}-0.03034 \\
-0.03034\end{array}$ & $\begin{array}{l}0.023352 \\
0.018115\end{array}$ & $\begin{array}{l}-0.0778 \\
-0.0672\end{array}$ & $\begin{array}{l}0.01712 \\
0.00652\end{array}$ \\
\hline Treynor & $\begin{array}{l}\text { Equal variances } \\
\text { assumed } \\
\text { Equal variances } \\
\text { not assumed }\end{array}$ & 0.528 & 0.472 & $\begin{array}{l}0.636 \\
0.584\end{array}$ & $\begin{array}{r}34 \\
17.833\end{array}$ & $\begin{array}{l}0.529 \\
0.567\end{array}$ & $\begin{array}{l}0.069667 \\
0.069667\end{array}$ & $\begin{array}{l}0.109468 \\
0.119294\end{array}$ & $\begin{array}{l}-0.1528 \\
-0.1811\end{array}$ & $\begin{array}{l}0.29213 \\
0.32046\end{array}$ \\
\hline Sharpe & $\begin{array}{l}\text { Equal variances } \\
\text { assumed } \\
\text { Equal variances } \\
\text { not assumed }\end{array}$ & 5.191 & 0.029 & $\begin{array}{l}-1.228 \\
-1.546\end{array}$ & $\begin{array}{r}34 \\
33.795\end{array}$ & $\begin{array}{l}0.228 \\
0.131\end{array}$ & $\begin{array}{l}-0.17233 \\
-0.17233\end{array}$ & $\begin{array}{l}0.140351 \\
0.111444\end{array}$ & $\begin{array}{l}-0.4576 \\
-0.3989\end{array}$ & $\begin{array}{r}0.11289 \\
0.0542\end{array}$ \\
\hline Jensen & $\begin{array}{l}\text { Equal variances } \\
\text { assumed } \\
\text { Equal variances } \\
\text { not assumed }\end{array}$ & 12.325 & 0.001 & $\begin{array}{l}-2.032 \\
-2.517\end{array}$ & $\begin{array}{r}34 \\
33.998\end{array}$ & $\begin{array}{r}0.05 \\
0.017\end{array}$ & $\begin{array}{l}-0.03225 \\
-0.03225\end{array}$ & $\begin{array}{l}0.015873 \\
0.012812\end{array}$ & $\begin{array}{l}-0.0645 \\
-0.0583\end{array}$ & $\begin{array}{l}6.8 \mathrm{E}-06 \\
-0.0062\end{array}$ \\
\hline
\end{tabular}

Sumber: data diolah (2017)

Hasil dari independent $\mathrm{t}$ test yang dilakukan melalui index Jensen didapatkan hasil T Tabel $2.032 \leq \mathrm{T}$ hitung $-2,032 \leq \mathrm{T}$ Tabel 2.032 dan sig (2-tailed) $0,05 \leq 0,05$, hal ini menunjukan bahwa H1 ditolak atau HO diterima artinya tidak ada perbedaan signifikan antara reksadana konvensional pendapatan tetap dan reksadana syariah pendapatan tetap yang diuji dengan indeks Jensen. 
Tabel 6. Uji Independent T-Test Konvensional Saham dan Syariah Saham

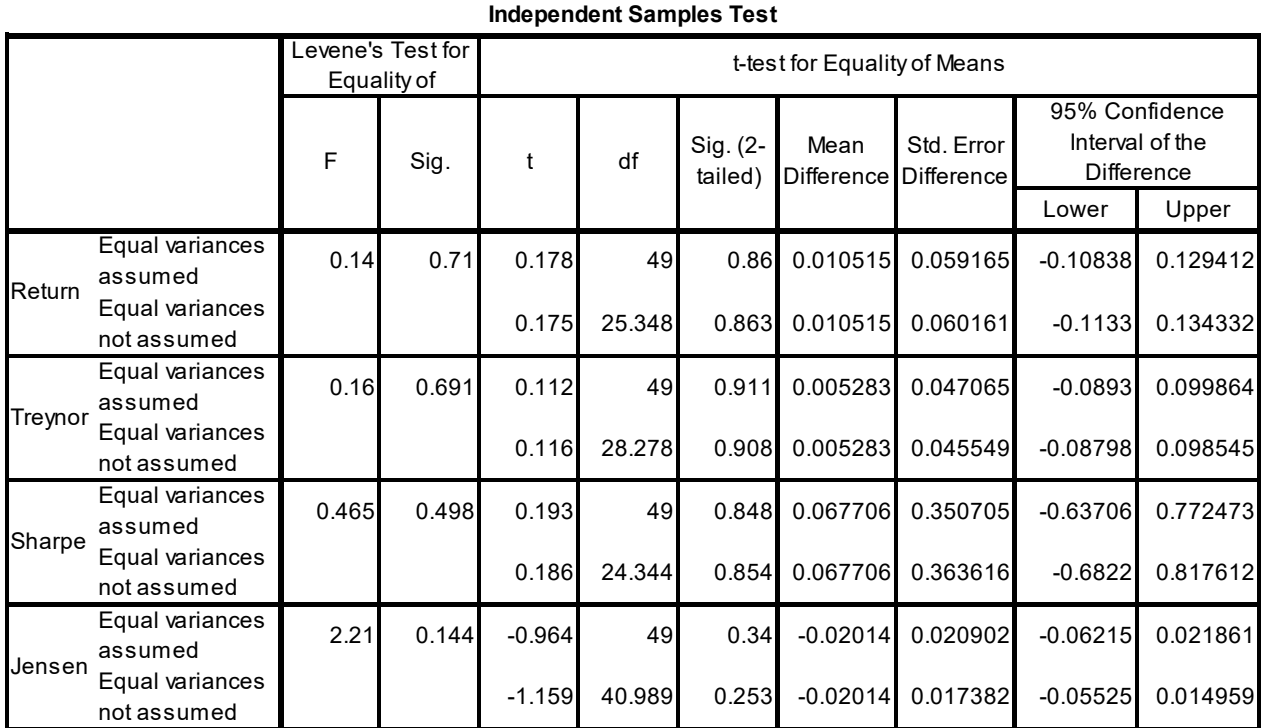

Sumber: data diolah (2017)

Dalam Tabel 6. uji independen $\mathrm{t}$ test digunakan untuk menguji apakah kedua kelompok reksadana konvensional saham dan syariah saham memiliki rata-rata yang sama. Hasil dari independent $\mathrm{t}$ test yang dilakukan pada return didapatkan hasil T hitung 0,178 $\leq$ T Tabel 2.010 dan sig (2-tailed) 0,86 $\geq 0,05$, hal ini menunjukan bahwa $\mathrm{H} 2$ ditolak atau Ho diterima artinya tidak ada perbedaan signifikan antara reksadana konvensional saham dan reksadana syariah saham yang diuji pada return.

Hasil dari independent $\mathrm{t}$ test yang dilakukan melalui index Treynor didapatkan hasil $\mathrm{T}$ hitung $0,112 \leq$ T Tabel 2.010 dan sig (2-tailed) 0,911 $\geq 0,05$, hal ini menunjukan bahwa H2 ditolak atau Ho diterima artinya tidak ada perbedaan signifikan antara reksadana konvensional saham dan reksadana syariah saham yang diuji dengan indeks Treynor.

Melalui index Sharpe didapatkan hasil T hitung 0,193 $\leq$ T Tabel 2.010 dan sig (2-tailed) 0,848 $\geq$ 0,05, hal ini menunjukan bahwa ha ditolak atau Ho diterima artinya tidak ada perbedaan signifikan antara reksadana konvensional saham dan reksadana syariah saham yang diuji dengan indeks Sharpe.

Hasil dari independent $\mathrm{t}$ test yang dilakukan melalui index Jensen didapatkan hasil $\mathrm{T}$ Tabel $2.010 \leq$ T hitung $-0,964 \leq \mathrm{T}$ Tabel 2.010 dan sig (2-tailed) $0,36<0,05$, hal ini menunjukan bahwa H2 diterima atau Ho ditolak artinya ada perbedaan signifikan antara reksadana konvensional saham dan reksadana saham yang diuji dengan indeks Jensen.

\section{DISKUSI}

Menurut Santosa dan Puspitasari (2019) dan Fikasari (2012) ada kecenderungan bahwa investor lebih memilih risiko yang terendah namun memiliki return tertentu yang tinggi, dengan cara mengevaluasi kinerja reksadana investor dapat mengetahui korelasi risiko dan imbal hasil yang diperoleh dari investasi reksadan, baik konvensional maupun syariah. Untuk itu investor harus mengerti perhitungan dan memahami return reksadana agar dapat berinvestasi dengan baik dan mengetahui ekspektasi keuntungan yang didapat (Bodie et al. 2014; Jones, 2017).

\section{Pembahasan Perbandingan Reksadana Konvensional Pendapatan Tetap Dan Reksadana} Syariah Pendapatan Tetap 
Dari hasil yang didapatkan dari penelitian ini bahwa reksadana konvensional pendapatan tetap dan reksadana syariah pendapatan tetap mempunyai return yang hampir mirip. Pada tahun 2014 reksadana syariah pendapatan tetap 4 reksadana mempunyai return yang positif dan reksadana konvensional pendapatan tetap 6 mempunyai return positif dan 2 mempunyai return negatif. Pada tahun 2015 return mengalami penurunan pada reksadana syariah pendapatan tetap 4 reksadana mempunyai return positif dan reksadana konvensional 4 mempunyai return positif daan 4 mempunyai return yang negatif. Pada tahun 2016 return kembali meningkat pada reksadana syariah pendapatan tetap 4 mempunyai return positif dan reksadana konvensional 7 mempunyai return positif dan 1 mempunyai return yang negatif.

Dalam hal ini menunjukan bahwa reksadana syariah pendapatan tetap lebih stabil dibandingkan dengan reksadana konvensional pendapatan tetap. Karena reksadana syariah mempunyai risiko yang lebih rendah tetapi mempunyai return yang tidah jauh berbeda. Hasil penelitian ini didukung oleh penelitian sebelumnya yang dilakukan oleh Kartini dan Febrianto (2015) dan Warsin, Suhartati dan Fatimah (2011) dan Putra, J. dan Fauzie, S. (2015) yang menyatakan bahwa risiko reksadana syariah lebih rendah dan mempunyai return yang hampir mirip dengan konvensional.

Dalam hasil uji independent t-test yang dilakukan terdapat hasil yang menyatakan bahwa kinerja reksadana konvensional pendapatan tetap dan reksadana syariah pendapatan tetap mempunyai hasil return sig (2-tailed) 0,203, metode Treynor sig. (2-tailed) 0,529, hasil metode Sharpe sig. (2-tailed) 0,228 dan hasil metode Jensen didapatkan hasil sig. (2-tailed) $0,05 \geq 0,05$ yang mempunyai sig. (2-tailed) $\geq 0,05$ hal tersebut membuktikan bahwa tidak terdapat perbedaan yang signifikan antara reksadana pendapatan tetap syariah dengan reksadana pendapatan tetap konvensional.

Hasil penelitian ini didukung oleh penelitian sebelumnya yang dilakukan oleh Jepryansyah (2014) yang juga mendapatkan hasil pada pengujian reksadana pendapatan tetap pada metode Treynor, metode Sharpe dan metode Jensen tidak mempunyai perbedaan yang signifikan. Hasil penelitian ini juga didukung oleh Yuliati (2013) dan Eka et al. (2012) yang menyatakan bahwa pada return, metode Treynor, metode Sharpe dan metode Jensen tidak mempunyai perbedaan yang signifikan.

\section{Pembahasan Perbandingan Reksadana Konvensional Saham Dan Reksadana Syariah Saham}

Dari hasil yang didapatkan penelitian ini bahwa reksadana konvensional saham dan reksadana syariah saham mempunyai return yang hampir mirip. Pada tahun 2014 reksadana syariah saham 5 reksadana mempunyai return yang positif dan reksadana konvensional saham 12 mempunyai return positif. Pada tahun 2015 return mengalami penurunan pada reksadana syariah saham 5 reksadana mempunyai return negatif dan reksadana konvensional saham 12 mempunyai return negatif. Pada tahun 2016 return kembali meningkat pada reksadana syariah saham 5 mempunyai return positif dan reksadana konvensional saham 11 mempunyai return positif dan 1 mempunyai return yang negatif.

Dalam hal ini menunjukan bahwa reksadana syariah saham mempunyai return yang hampir mirip dibandingkan dengan reksadana konvensional saham. Reksadana syariah saham dan konvensional saham mempunyai risiko dan return yang tidah jauh berbeda, tetapi reksadana syariah menjalankan syariat Islam. Hasil penelitian ini didukung oleh penelitian sebelumnya yang dilakukan oleh Kartini dan Febrianto (2015), Agung et al. (2014) dan Liyanasari, R. (2014) yang menyatakan bahwa risiko dan return syariah saham hampir mirip dengan konvensional saham.

Dalam hasil uji independent t-test yang dilakukan terdapat hasil yang menyatakan bahwa kinerja reksadana konvensional saham dan reksadana syariah saham mempunyai hasil metode Treynor sig. (2-tailed) 0,911 dan hasil metode Sharpe sig. (2-tailed) 0,848 yang mempunyai sig. (2-tailed) $\geq 0,05$ hal tersebut membuktikan bahwa tidak terdapat perbedaan yang signifikan. Sedangkan hasil metode 
Jensen sig. (2-tailed) 0,34<0,05 sig. (2-tailed) hal ini membuktikan bahwa pada metode Jensen terdapat perbedaan antara reksadana saham syariah dengan reksadana saham konvensional.

Hasil penelitian ini didukung oleh Ratnawati dan Khairunisa (2012) dan Putra dan Fauzie (2014) yang mendapatkan hasil pada pengujian reksadana pendapatan saham pada metode Treynor dan metode Sharpe tidak mempunyai perbedaan signifikan. Sedangkan dan metode Jensen terdapat perbedaan pada reksadana saham konvensional dan reksadana saham syariah. Hasil penelitian ini juga didukung oleh Liyanasari (2014) dan Lestari (2015) yang mendapatkan hasil bahwa pada return tidak mempunyai perbedaan yang signifikan. Penelitian ini juga di dukung oleh Ferdian dan Dewi (2012) dan Lestari (2015) Hasil independent samples test menunjukkan bahwa return, indeks Sharpe dan indeks Treynor tidak ada perbedaan signifikan antara kinerja reksadana saham konvensional dan kinerja reksadana saham syariah. Pada indeks Jensen ada perbedaan signifikan antara kinerja reksadana saham konvensional dan kinerja reksadana saham syariah.

\section{SIMPULAN}

Berdasarkan hasil analisis dan pembahasan yang telah dilakukan sebelumnya, maka dapat diambil kesimpulan bahwa:

1. Berdasarkan perhitungan keuntungan (return) pada reksadana pendapatan tetap didapatkan hasil bahwa pada tahun 2014 reksadana pendapatan tetap konvensional mempunyai return yang lebih besar dari return pendapatan tetap syariah tetapi ada beberapa return reksadana pendapatan tetap konvensional yang mempunyai return minus sedangkan return reksadana pendapatan tetap syariah positif semua. Pada tahun 2015 reksadana pendapatan tetap konvensional mempunyai return yang lebih besar dari return pendapatan tetap syariah tetapi ada beberapa return reksadana pendapatan tetap konvensional yang mempunyai return negatif sedangkan return reksadana pendapatan tetap syariah positif semua. Pada tahun 2016 reksadana pendapatan tetap syariah mempunyai return yang lebih besar dari return pendapatan tetap konvensional.

2. Berdasarkan perhitungan keuntungan (return) pada reksadana syariah saham mempunyai return yang tidak jauh berbeda dibandingkan dengan reksadana konvensional saham. Reksadana syariah saham dan konvensional saham mempunyai risiko dan return yang tidah jauh berbeda, tetapi reksadana syariah menjalankan syariat Islam. Pada tahun 2014 reksadana saham konvensional mempunyai return yang lebih besar dari return saham syariah dan hasil return 2014 semua bernilai positif pada 2015 reksadana saham konvensional mempunyai return yang lebih besar dari return saham syariah dan hasil return reksadana saham 2015 semua bernilai negatif. pada tahun 2016 reksadana saham konvensional mempunyai return yang lebih besar dari return saham syariah dan hasil return reksadana saham 2016 hanya 1 reksadana konvensional yang bernilai negatif.

3. Berdasarkan hasil uji independent t-test yang dilakukan terdapat hasil yang menyatakan bahwa kinerja reksadana konvensional pendapatan tetap dan reksadana syariah pendapatan tetap mempunyai hasil metode Treynor, metode Sharpe dan metode Jensen tersebut membuktikan bahwa tidak terdapat perbedaan yang signifikan antara reksadana konvensional pendapatan tetap dan reksadana syariah pendapatan tetap.

4. Dalam hasil uji independent t-test yang dilakukan terdapat hasil yang menyatakan bahwa kinerja reksadana konvensional saham dan reksadana syariah saham mempunyai hasil metode Treynor dan metode Sharpe membuktikan bahwa tidak terdapat perbedaan yang signifikan pada reksadana konvensional saham dan reksadana syariah saham. Pada metode Jensen di dapatkan hasil yang menunjukkan terdapat perbedaan yang sinifikan antara reksadana konvensional pendapatan tetap dan reksadana syariah pendapatan tetap. 


\section{REFERENSI}

Agung, J.R., Sukma, D.M. dan Wirasedana, I.W.P. (2014). Analisis Kinerja Reksadana Saham di Indonesia. E-Jurnal Akutansi. Universitas Udayana, Bali.

Bodie, Z., Kane, A., Marcus, A.J. (2014). Essentilas of Investments, 10 Edition, New York: McGraw- Hill.

Esha, M.R., Heykal, M. dan Indrawati, T. (2014). Analisis Perbandingan Reksadana Saham Syariah Dengan Reksadana Saham Konvensional Periode 2009-2012. Binus Business Review, 5(1).

Ferdian, I.R. dan Dewi, M. K. (2012). Evaluating Performance of Islamic Mutual Funds In Indonesia And Malaysia. Journal of Applied Economic and Business Research JAEBR.

Ghofur, A. Aspek Hukum Reksa Dana Syariah di Indonesia. Refika Aditama, Bandung, 2008

Ibrahim, L. (2011). Analisis Perbandingan Kinerja Reksadana Konvensional Dan Reksadana Syariah Jenis Reksadana Pendapatan Tetap Periode 2008-2011. [Skripsi]. Institut Teknologi Telkom, Bandung.

Putra, J. dan Fauzie, S. (2015). Analisis Perbandingan Kinerja Reksadana Konvensional Dengan Reksadana Syariah Di Indonesia. Jurnal Ekonomi dan Keuangan, 2(5).

Kartini dan Febrianto, R. (2011). Analisis Perbandingan Kinerja Reksadana Konvensional dengan Kinerja Reksadana Syariah. Jurnal Bisnis dan Ekonomi, Vol. 2 No.1.

Kasmiati, M. dan Santosa, P. W. (2019). The effect of earning information, cash flow components, and financing decision on stock returns: empirical evidence on Indonesia stock exchange, Journal of Economics, Business, and Accountancy Ventura, 22(2), 157-166.

Lestari, W.R. (2015). Kinerja Reksadana Saham dan Reksadana Saham Konvensional. Jurnal Magister Manajemen Vol 1, No.1.

Liyanasari, R. (2014). Analisis Perbandingan Kinerja Portofolio Optimal Pada Saham Syariah Indonesia Dan Saham Syariah Malaysia Periode 2009-2012. [Skripsi]. Universitas Islam Negri Maulana Malik Ibrahim, Malang.

Pujiarti, T. dan Dewi, F. R. (2011). Analisis Kinerja Reksadana Saham dengan Menggunakan Metode Sharpe dan Jensen untuk Periode 2005-2009. Jurnal Manajemen dan Organisasi, 2(2).

Ratnawati, V. dan Khairani, N. (2012). Perbandingan Kinerja Reksa Dana Syariah dan Reksa Dana Konvensional. Jurnal Akuntansi, 1(1).

Fikasari, R. N. (2012). Analisis Komparatif Kinerja Reksadana Syariah Indonesia Dan Malaysia. [Skripsi.] Universitas Islam Negeri Maulana Malik Ibrahim, Malang.

Samsul, Muhammad. (2015). Pasar Modal dan Manajemen Portofolio. Penerbit Erlangga: Jakarta.

Santosa, P. W. (2019). Financial Performance, Exchange Rate and Stock Return: Evidence from Manufacturing Sector at IDX, Jurnal Manajemen Teknologi, 18(3), 205-217.

Santosa, P.W dan Laksana, H.Y. (2011). Value at Risk, Market Risk and Trading Activity: CAPM Alternative Model. Journal of Applied Finance and Banking, 1(4), 239-268.

Santosa, P. W. \& Hidayat, A. (2014). Riset Terapan: Teori dan Aplikasi, Edisi Pertama, Jakarta: Globalstat Press.

Santosa, P.W. dan Puspitasari, N. (2019). Corporate Fundamentals, BI Rate and Systematic Risk: Evidence from Indonesia Stock Exchange, Jurnal Manajemen, 23(1), 39-52.

Santosa, M. dan Amelia. (2012). Penilaian Produk Reksadana dengan Menggunakan Perhitungan Jensen Alpha, Shape Ratio Treynor Ratio $\mathrm{M}^{2}$, Information Ratio. Jurnal Manajemen, 12(1).

Sugiyono. Metodologi Penelitian Pendidikan, Pendekatan Kuantitatif, Kualitatif dan Re D. Alfabeta. Bandung, 2009

Tandelilin, E. (2014). Portofolio dan Investasi Teori dan Aplikasi Edisi (I). Penerbit Kanisius: Yogyakarta.

Wahdah, R. dan Hartanto, J. (2012). Analisis Pengukuran Kinerja Reksa dana Saham Di Indonesia. Jurnal Manajemen dan Akuntansi, 13(1).

Warsini, S., Suhartati, T. dan Fatimah, H. (2011). Pengukuran Kinerja Reksadana dengan Menggunakan Besaran Alpha Hasil Perhitungan Metode Jensen di Pasar Modal Indonesia. Jurnal Ekonomi dan Bisnis, 10(1).

Widjaja, G dan Ramaniya, A.P. (2009). Reksadana dan peran serta tanggung jawab Manajer Investasi dalam Pasar Modal: Seri Pengetahuan Pasar Modal. Penerbit Kencana: Jakarta. 
Lestari, W.R. (2015). Kinerja Reksadana Saham Syariah Dan Reksadana Saham Konvensional. Jurnal Magister Manajemen, 1(1).

Yuliaty, R. (2013). Analisis Komparatif Kinerja Reksadana Saham Konvensional dengan Reksadana Saham Syariah dengan Menggunakan metode Sharpe, Treynor, dan Jensen pada Bursa Efek Indonesia Periode Tahun 2010. [Skripsi.] Universitas Diponegoro, Semarang. 